\title{
The humus of a "Parabraunerde" (Orthic Luvisol) under Fagus sylvatica $L$ and Quercus robur $L$ and its modification in 25 years
}

\author{
L Beyer $1^{*}$, HP Blume 1, U Irmler 2 \\ ${ }^{1}$ University of Kiel, Institute of Plant Nutrition and Soil Science, \\ Hermann-Rodewald Strasse 2; \\ ${ }^{2}$ University of Kiel, Research Station of Ecosystems and Ecotechnics, \\ Olshausenstrasse 40-60, $2300 \mathrm{Kiel}$ 1, Germany
}

(Received 18 July 1990; accepted 21 January 1991)

\begin{abstract}
Summary - The humus of a loamy Orthic Luvisol containing a rich soil fauna formed on a boulder marl in the low-lying plain in the northwest of Germany near the Baltic sea under beech and oak with a mull humus was investigated in 1965 and 1986. Using a wet chemical procedure litter (proteins, polysaccharides, lignins) and humic components (fulvic and humic acids, humins) were separated. The results were combined with micro- and macromorphological observations and microbiotic and zootic investigations. The humus body has changed during the past 25 years. Decreasing bioturbation has induced a differentiation of the horizons in the organic layer, an accumulation of litter components and the development of an L- and an Oh-layer. The Of-layer has become tangled and laminated. The $\mathrm{pH}$ has decreased by half a unit. The translocation of fulvic acids has increased and the first signs of podzolization have been documented. The intensity of decomposition and humification has decreased during the past 25 years and therefore the humus form has changed from mull to moder. The main reason for this may be the decline of the earthworm population because of the lower $\mathrm{pH}$ and the deficiency of calcium as a consequence of the acid and proton input by air pollution.
\end{abstract}

humus morphology / humus chemistry / Orthic Luvisol / soil acidification / humus transformation

Résumé - L'humus d'un «Parabraunerde» (sol brun lessivé) sous hêtre (Fagus sylvatica $L$ ) et chêne rouvre (Quercus robur $L$ ) et son évolution au cours des 25 dernières années. L'humus du sol d'une hêtraie-chênaie à mull a fait l'objet de recherches et d'analyses comparées en 1965 et 1986. I/ s'agit d'un sol brun lessivé limoneux, biologiquement actif, sur marnes morainiques d'une plaine basse de l'Allemagne du Nord près de la Baltique. On a procédé au fractionnement par voie humide des composés des litières (protéines, polysaccharides, lignine) et des composés humiques (acides fulvique et humiques, humines). Les résultats obtenus ont été confrontés avec les observations de micro- et macromorphologie, ainsi qu'avec les résultats des études microbilogiques et fauniques. Les humus se sont transformés au cours des 25 dernières années. La diminution de l'activité faunique a provoqué une différenciation plus marquée des horizons organiques, une accumulation en surface des composés de la litière, et enfin le développement d'une couche $L$ et d'une couche Oh. La couche Of a pris l'aspect enchevêtré et laminé. Le pH a diminué d'une demi-unité. L'entrainement en profondeur des acides a augmenté et les premiers symptômes de la podzolisation apparaissent. En raison du ralentissement de la décomposition des litières et de l'humification,

${ }^{*}$ Correspondence and reprints 
au cours des 25 dernières années, le type d'humus est passé du mull au moder. La principale cause de cette transformation semble résider dans la décroissance de la population de lonbrics, liée à la baisse du pH et au déficit en calcium, conséquence de l'apport des protons et de produits acides liés à la pollution atmosphèrique.

morphologie de l'humus / chimie de l'humus / sol brun lessivé / acidification du sol / transformation de l'humus

\section{INTRODUCTION}

The soils in the mid-European forests have changed due to the deposition from air pollution (Ulrich, 1989a). Soil acidification is regarded as a primary reason for this process (von Zezschwitz, 1985). However, base saturation and $\mathrm{pH}$ value have an effect on rooting (Ulrich, 1989b), the humification of organic matter (Abrahamsen et al, 1980; Baath et al, 1980; Uirich, 1989a) and the formation of the humus body (Diagne, 1982; von Zezschwitz, 1989).

At the 13th Congress of the International Society of Soil Science in Hamburg in 1986, an Orthic Luvisol under beech and oak was shown during an excursion in Schleswig-Holstein. Its humus composition was presented by using data from 1960 (Blume et al, 1986). The investigations were based on extensive macro- and micromorphological observations and wet chemical investigations (Blume, 1965).

Due to the discussion about "forest decline" it seemed very interesting to compare the results from 1960 with those from 1986 at the same site. We hoped to demonstrate changes in the humus body and the retardation of litter decay caused by the soil acidification.

\section{MATERIALS AND METHODS}

A loamy Orthic Luvisol (Typische Parabraunerde, Typic Hapludalf, Sol brun lessivé) formed in the Weichselian boulder marl over fluvioglacial sands was investigated. It is located in the eastern hills in Schleswig-Holstein under a Melico-Fagetum vegetation with Quercus robur. The mean age of the stand is $\approx 90 \mathrm{yr}$ old. Soil acidification is very advanced $\left(\mathrm{pH}_{\mathrm{CaCl}_{2}}\right.$ 3.6) and the topsoil is poor in nutrients. Nevertheless, the large nutrient reserves in the subsoil result in highly productive beech trees, whose roots reach the boulder marl containing carbonates. The soil and the site have been described by Blume et al (1986) and Duchaufour (1987). The annual precipitation is $560 \mathrm{~mm}$ and the average temperature is $8.4^{\circ} \mathrm{C}$

In early October 1960 and 1986 sampling for humus characterization (area $1 \mathrm{~m}^{2}$ ) was carried out before the main litter fall and after mapping the humus form and the typical sequence of the horizons in the organic layer of this beech stand. The morphology of a typical profile was described according to Brewer and Sleeman (1960), Schlichting and Blume (1966) and AK Standortskartierung (1982). In order to determine the litter and humus component groups, air-dried soil samples were analysed wet chemically according to Schlichting and Blume (1966). Fat and waxes were extracted with ethanol/ benzene; sugar and starch with $0.05 \mathrm{~N} \mathrm{H}_{2} \mathrm{SO}_{4}$ (the amounts of this fraction were always $<<1 \%$ of $\mathrm{C}_{\mathrm{org}}$ and were therefore added to the hemicellulose fraction); hemicellulose with $0.6 \mathrm{~N} \mathrm{HCl}$, cellulose with $27 \mathrm{~N} \mathrm{H}_{2} \mathrm{SO}_{4}$; mobile fulvic acids with $0.05 \mathrm{~N} \mathrm{H}_{2} \mathrm{SO}_{4}$ and fulvic and humic acids with $0.1 \mathrm{~N} \mathrm{NaOH}$ and $0.1 \mathrm{~N} \mathrm{H}_{2} \mathrm{SO}_{4}$ alternately. Proteins were estimated as $\alpha-\mathrm{NH}_{2}-\mathrm{N} \times 6.25$ by determination of $\alpha-\mathrm{NH}_{2}-\mathrm{N}$ by hydrolysis with $6 \mathrm{~N}$ $\mathrm{HCl}$ and $1 \mathrm{~N} \mathrm{HCOOH}$. Lignins were estimated as $\mathrm{OCH}_{3} \times 10.5$ by determination of $\mathrm{OCH}_{3}$ by using the Zeisl-Pregl method. The determination of carbon in the solution was carried out using Ströhlein apparatus. The determination of carbon and nitrogen in the solid state was carried out in the CHN analyser; for a more detailed description of the analyses, see Beyer (1989). 
The thickness of the organic layer was measured every $6 \mathrm{wk}$ (10 replicates). The litter fall was estimated quantitatively every month from an area of $1 \mathrm{~m}^{2}$ (5 replicates). The soil respiration was measured fortnightly using Lundegardh cylinders (5 replicates); for further information see Beyer (1989). The soil fauna was ascertained in 3 layers ( 3 replicates): the soil surface and soil vegetation (vacuum trap), the litter layer (hand selection or expulsion in KempsonTullgren apparatus) and the topsoil (expulsion in Kempson-Tullgren apparatus). The litter decomposition was observed using net bags (mesh size $0.5 \mathrm{~cm}$ ) which were filled with $8 \mathrm{~g}$ autumnal leaf litter. The determination of dry weight was carried out on 3 of the net bags at 2-month intervals (sampling at 8 dates with 3 replicates). The rate of decomposition was calculated according to Olson (1963).

\section{RESULTS}

\section{Humus morphology}

In October 1960 the humus horizons had the following morphology (see fig 1a; the thickness of the horizon is in brackets):

\section{Lof (3-1)}

$40 \%$ whole twigs and $60 \%$ wavy, nibbled leaves and leaf pieces $\left(0.03 \mathrm{~g} / \mathrm{cm}^{3}\right)$.

\section{Of (1-0)}

Broken, skeletal leaf pieces, fruit shells and twig pieces with faeces $\left(0.13 \mathrm{~g} / \mathrm{cm}^{3}\right)$. The leaf surfaces are covered with faeces.

\section{OAh (0-2)}

$30 \%$ leaf and twig pieces and $70 \%$ arthropod and worm faeces. The earth worm faeces contain $\approx 50 \%$ mineral particles.

\section{Ah1 (2-5)}

Sandy loam, little litter and many animal faeces $\left(0.26 \mathrm{~g} / \mathrm{cm}^{3}\right)$. The worm faeces (giving a crumb structure) contain only $20 \%$ organic matter.
Ah2 (5-16)

Grey-brown sandy loam with crumb structure $\left(1.4 \mathrm{~g} / \mathrm{cm}^{3}\right)$.

Alv (16-47)

Closely packed, brown loam $\left(1.6 \mathrm{~g} / \mathrm{cm}^{3}\right)$ with a subpolyhedric to polyhedric structure with asepic to sepic plasma.

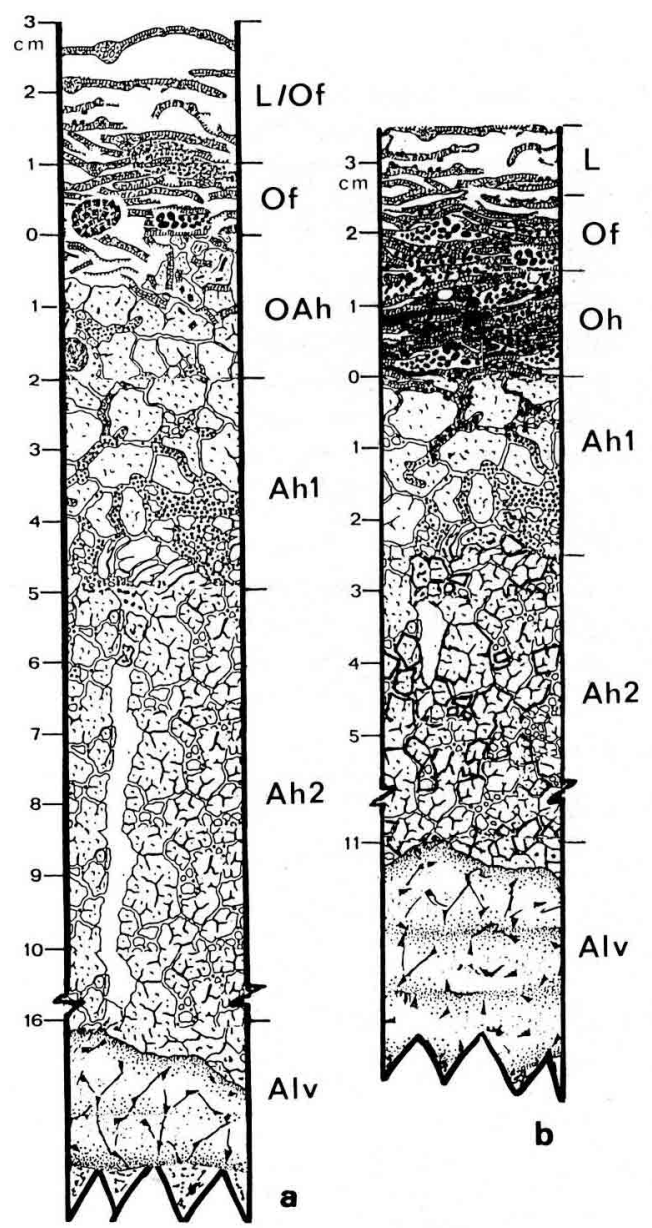

Fig 1. a) Morphology of an F-mull of an Orthic Luvisol under beech and oak in 1960 in northwest Germany. b) Morphology of a moder, poor in fine humus of an Orthic Luvisol under beech and oak in 1986 in northwest Germany. 
In October 1986 the humus horizons had the following morphology (see fig 1b); the thickness of the horizon is in brackets).

\section{$L$ (5.5-3.5)}

$50 \%$ whole twigs and wavy, $50 \%$ nibbled leaves and leaf pieces $\left(0.05 \mathrm{~g} / \mathrm{cm}^{3}\right)$. The leaf surfaces are covered with Collembola faeces.

\section{Of (3.5-1.5)}

$20 \%$ fibrous twigs and skeletal leaf pieces. The leaf pieces and the Enchytraeidae and Oribatidae faecal pellets are stored in alternate layers $\left(0.02 \mathrm{~g} / \mathrm{cm}^{3}\right)$.

Oh (1.5-0.0)

Compact fine humus and mineral particles $\left(0.21 \mathrm{~g} / \mathrm{cm}^{3}\right)$; plant tissue is almost completely decomposed and humified; Oribatidae faeces, an increased amounts of Enchytraeidae faeces and small amounts of worm faeces are also present.

\section{Ah1 (0-2.5)}

Loamy, slightly bleached sand with fine crumb structure $\left(1.1 \mathrm{~g} / \mathrm{cm}^{3}\right)$; the remains of the litter are less humified, and there are tunnels containing $\mathrm{Oh}$ and $\mathrm{Of}$ material; Enchytraeidae faeces are dominant, as are cavities containing worm faeces.

Ah2 (2.5-11)

Strong loamy sand with crumb to fine polyhedric structure and a small amount of litter $\left(1.1 \mathrm{~g} / \mathrm{cm}^{3}\right)$.

\section{Alv (11-47)}

Sandy loam $\left(1.62 \mathrm{~g} / \mathrm{cm}^{3}\right)$ with coarse polyhedric structure with asepic to skel- and mosepic plasma.

The litter was composed of leaves, twigs, fruits and their involucres and leafbud hulls of trees and necrotic herb vegetation. The thickness of the litter layer and the litter supply of varied greatly during the annual cycle (fig 2). Earthworms especially caused intensive bioturbation in this Luvisol. The Enchytraeidae participated in the decomposition of litter. They caused the characteristic fine crumbs (natural $\varnothing<1$ $\mathrm{mm}$; fig 1), whereas earthworm activity resulted in the formation of crumbs (natural $\emptyset 1-10 \mathrm{~mm}$, fig 1). Nevertheless there were also many soil animals, which did not
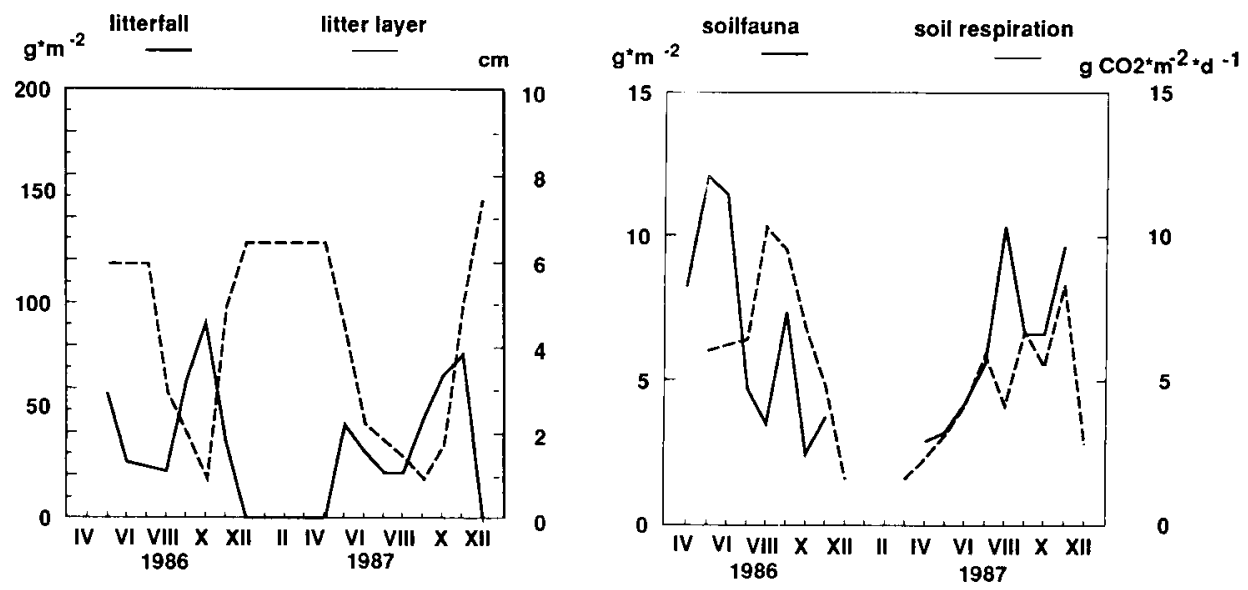

Fig 2. Annual litter fall, thickness of the litter layer, soil fauna and soil respiration of an Orthic Luvisol under beech and oak in northwest Germany. 


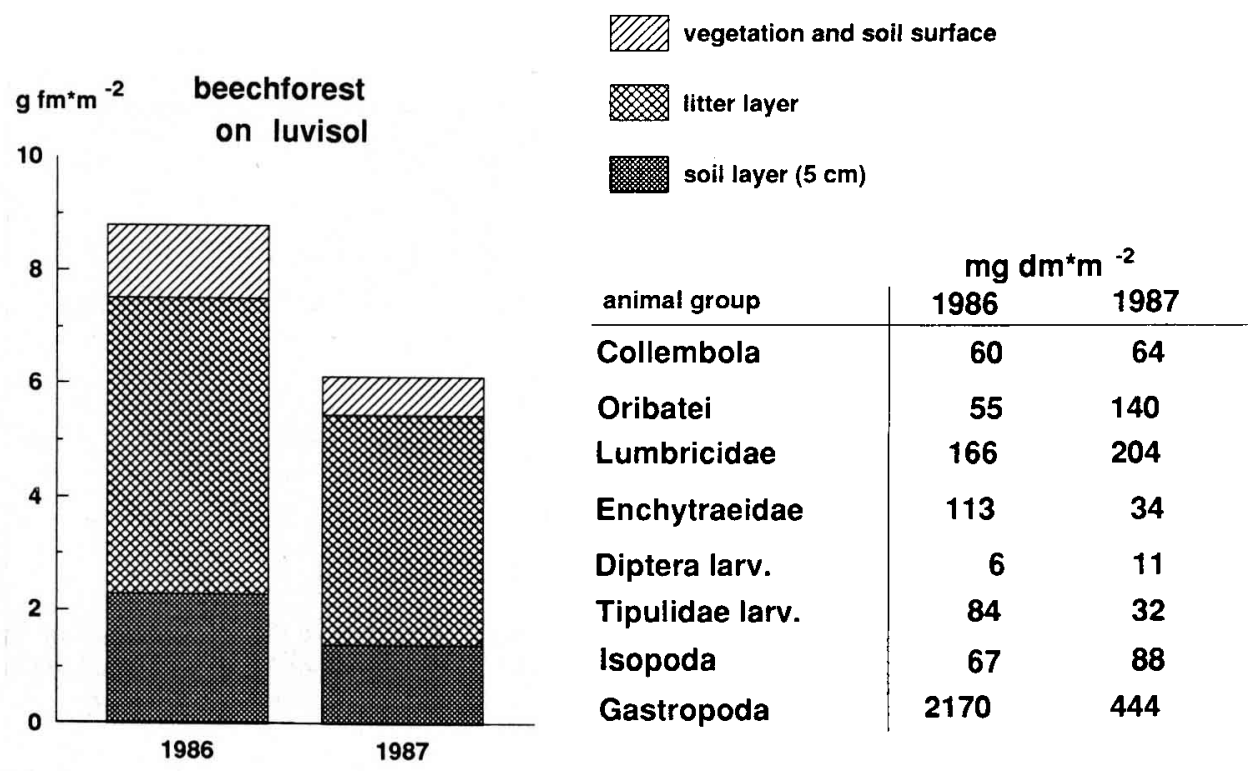

Fig 3. Composition of soil fauna in an Orthic Luvisol under beech and oak in northwest Germany.

alter this soil in such a remarkable way (fig 3), but stimulated decomposition by the micro-organisms (see soil respiration in fig 2). The largest part of the litter was incorporated and broken down within a year, so that the litter layer remained thin (fig 3), but each of the organic layers was to be found the whole year round.

\section{Humus chemistry}

The results of the chemical investijations of the humus are shown in figure 4 , and in tables I and II.

With increasing depth the litter components (fig 4: hc + cel + lig) decreased. Lignins were found to explain a large part of the carbon (fig 4), because they were present in fine roots. The increase of proteins was caused by presence of microorganism protein in the mineral soil. Humic substances increased in contrast to the litter. Fulvic acids were dominant. Most of the humins were probably humic acids fixed in clay-humus complexes (Blume, 1965). Therefore we have looked at the ha + hu/fa ratio (tables I, IV) instead of the ha/ fa ratio.

\section{COMPARISON OF THE INVESTIGATIONS IN 1960 AND 1986}

The carbon content in the soil was similar for both investigations with $\approx 8.5 \mathrm{~kg} / \mathrm{m}^{2}$ (table $(1,2)$, but the nitrogen content was higher in 1986 (table II, 1). However, it was not fixed in proteins, as these were not as high in 1986 (table II, 3). The largest nitrogen content was to be found in the Alv, where it was fixed in humic substances and also probably as $\mathrm{NH}_{4}{ }^{+}$in the clay mineral layers. In 1960 it was not possible to 
1960

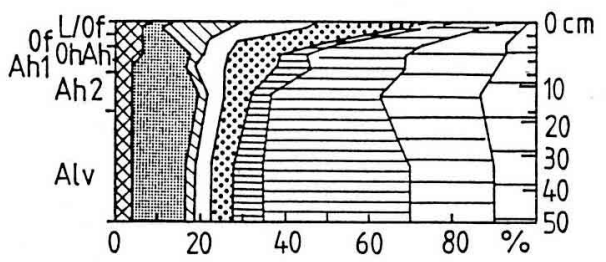

1986

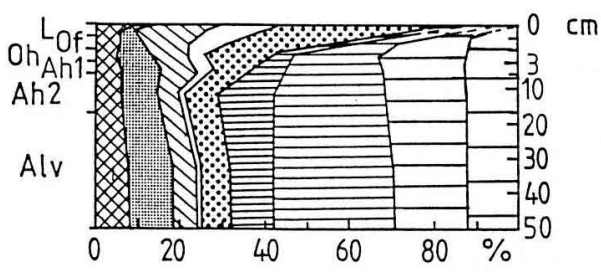

FA

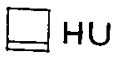

Fig 4. Humus chemistry of an Orthic Luvisol under beech/oak in northwest Germany in the fall of 1960 and 1986. (F/W: fats, waxes, resins; CEL: cellulose; HC: hemicellulose; PRO: proteins; LIN: lignins; MFA: mobile fulvic acids; FA: other fulvic acids; $\mathrm{HA}$ : humic acids; $\mathrm{HU}$ : humins in \% $\mathrm{C}_{\mathrm{org}}$ ).

document a real litter layer, which is why in the LOf humified material was to be found (fig 4). In 1960 there was less litter in the soil than in 1986 (table II, 4). The proportion of litter (fig 4) was lower in 1960 in the Of; in 1986 however, the lowest proportion was to be found in the Ah1horizon. In 1960 the bulk density of the Of was $0.13 \mathrm{~g} / \mathrm{cm}^{3}$; it contained only $9 \%$ twigs and arthropod faeces. In 1986 the bulk density was only $0.02 \mathrm{~g} / \mathrm{cm}^{3}$; it contained $26 \%$ twigs and there were no faeces in this horizon. This is the reason for the large difference in $\mathrm{C}_{\text {org }}$ (table $\mathrm{I}, 1$ ) and the completely different composition of the humus and litter components (table II). Whereas in 1986 the Of was more similar to the LOf, in 1960 it was more like an Ohf horizon. In contrast to 1986 , a real Oh was not be found in 1960. It was interesting that this horizon had the same carbon content as the Of in 1960. The OAh from 1960 was really an $A h$, because it contained only $16 \%$ humus (table $11: 2 \times \mathrm{C}_{\text {org }}$ ) and was comparable with the Ah1 recorded in 1986. A clear separation of the organic ho- rizons was more difficult in 1960 , because the horizons runs smoothly into one another due to the intensive bioturbation. In the $O$ horizon, humic substances which contain nitrogen were rebuilt and mixed with material from the Ah. This is the reason for a dilution in the mineral soil. Higher nitrogen levels in the Ah illustrate that this process was not as intensive in 1986. This reduction of the $\mathrm{C} / \mathrm{N}$ ratio in the $A$ h horizon has already been described by von Zezschwitz (1985). The increased proportion of carbon in the Ah confirms the change in the humus form (von Zezschwitz, 1980). In 1986 it was not possible to separate the organic horizons exactly, but neverthless a L-Of-Oh chronology was to be found the whole year round.

In 1986 the soil solution contained soluble organic carbon (Beyer, 1989). This carbon belonged to the mobile fulvic acids group, because the soil solution was yellow-brown coloured and water-soluble polysaccharides were not important (see Methods). In 1960 these mobile fulvic acids peaked in the Ah1 and slowly in- 
Humus transformation

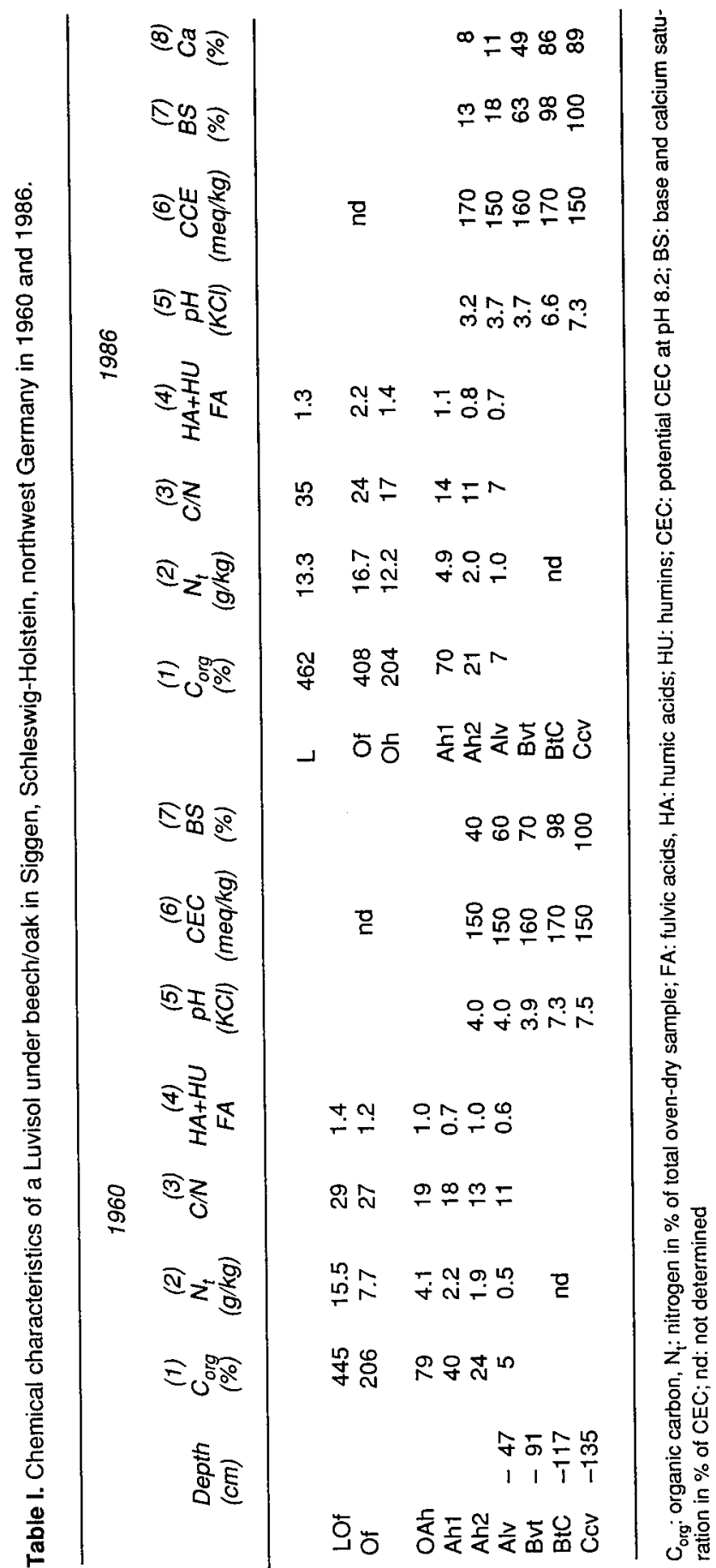




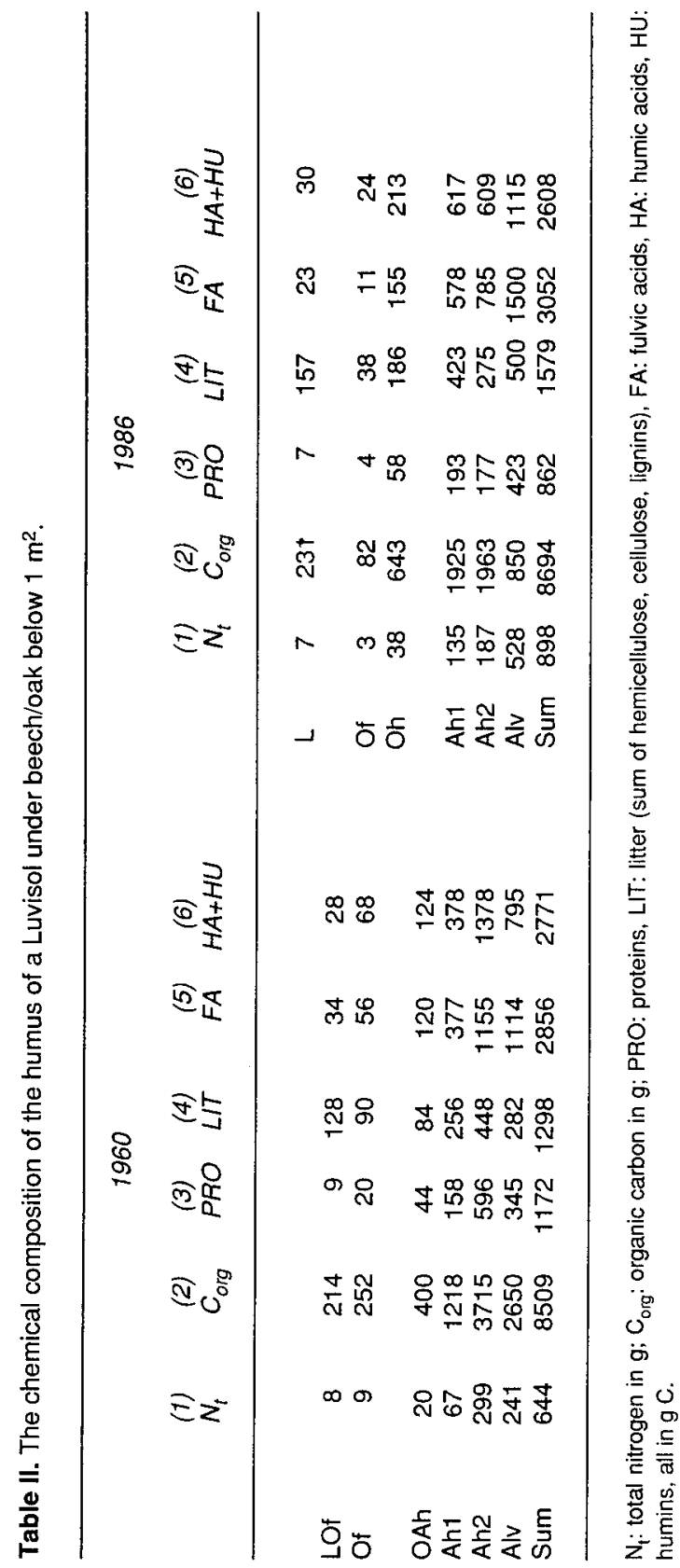


creased with increasing depth (fig 4). In 1986 this peak was located in the Ah2 at a much higher level. The humic acid + humin/fulvic acid ratio decreased continuously (table II, 4). The translocation of humic substances reached deeper horizons and was intensified. Morphologically the initial podzolization was documented by observing bleached mineral particles in the Ah1horizon. Von Zezschwitz (1979) has already described this in forest soils in west Germany.

The humus form has developed from a F-mull to a moder, poor in fine humus.

\section{DISCUSSION}

The decrease of the $\mathrm{pH}$ in the $\mathrm{A}$ horizon from 4.0 to 3.2 and the base saturation from 40 to $13 \%$ (table I, 5+7) in the past 25 $\mathrm{yr}$ has probably influenced the biocenosis of this soil ecosytem (Hartmann et al, 1989). Especially in the beech forest, which has only moderate resistance to acids, a higher aluminium concentration causes the mortality of fine roots (Ulrich et al, 1984). At a base saturation of below $10-15 \%$ (table 1,8 ) the damage to beech roots is possible because of an acidic soil solution (Ulrich et al, 1989). This is why a permanent regeneration of fine roots is necessary. This means that an accumulation of litter due to necrotic roots is one reason for the higher proportion of litter in 1986 (table II, 4).

The deposition of protons from the atmosphere into the soil $\left(4-6 \mathrm{~kg} \mathrm{NO}_{3}-\mathrm{N}, 7-\right.$ $14 \mathrm{~kg} \mathrm{NH}_{4}-\mathrm{N}, 11-20 \mathrm{~kg} \mathrm{SO}_{4}-\mathrm{S}$ and $0.4 \mathrm{~kg}$ $\mathrm{H}^{+} / \mathrm{ha}$ ) in Schleswig-Holstein is not insignificant (Blume et al, 1985). That is why we think that the natural process of acidification has been intensified by air pollution and deposition into the soil during the past few years. The $N$ input is at the lower end of the input levels described by Kreutzer (1989), but according to Blume et al (1985) in Schleswig-Holstein the largest part of the input is caused by $\mathrm{NH}_{3}$ emission from agriculture, due to intensive fertilization using slurry. The correlation between high $\mathrm{N}$ input and the decrease in the base saturation (table II, 7) and the simultaneous increase of $N$ supply (table II, 1) was documented by Kreutzer (1989) in spruce forests, but the same rule should apply to the beech site. Hallbäcken and Tamm (1986) were able to verify a decrease of $\mathrm{pH}$ in Swedish forest soils, which depends on the development of the trees after clear-felling. In 1960 the beech trees in Siggen were fully developed and already $50-60$ yr old and during the past few centuries the site has only been used for forestry. This is why the changes in the environmental conditions are only negligible: the shading of the soil, this means that the water and heat regimes, which are the most important parameters of decomposition and humification, were similar during the past 25 years.

The change in the humus form from mull to moder and the development of an organic layer was probably induced by a decrease in the earthworm population. In 1987, 19 earthworms $/ \mathrm{m}^{2}$ were recorded (table III). In a neighbouring site $2 \mathrm{yr}$ ago the $\mathrm{pH}$ was increased by liming, so that the $\mathrm{pH}$ value was the same as in 1960 (table III). This caused an abundance of these soil animals which was 5 times higher. The Lumbricidae need calcium for their physiology (Lee, 1985). The low supply of Ca (table $I, 8)$ in the top soil reduces the earthworm activity.

Soil degradation by the translocation of nutrient and humic substances to deeper soil horizons is stimulated by the beech trees, because no light comes through the 
Table III. Earthworms $\left(\mathrm{n} / \mathrm{m}^{2}\right)$ in the organic layer and the soil (depth $0-5 \mathrm{~cm}$ ) and annual average $\mathrm{pH}_{\mathrm{H}_{2} \mathrm{O}}$ depending on the liming (composition: $50 \% \mathrm{CaCO}_{3}$ and $35 \% \mathrm{MgCO}_{3}$ ) in May 1985.

\begin{tabular}{|c|c|c|c|c|c|c|}
\hline \multirow{2}{*}{$\begin{array}{l}\text { Lime } \\
\left(g / m^{2}\right)\end{array}$} & \multicolumn{2}{|c|}{1985} & \multicolumn{2}{|l|}{1986} & \multicolumn{2}{|c|}{1987} \\
\hline & $p H$ & $n / m^{2}$ & $\rho H$ & $n / m^{2}$ & $p H$ & $n / m^{2}$ \\
\hline 0 & 3.7 & 15 & 3.5 & 26 & 3.9 & 19 \\
\hline 300 & 4.0 & 27 & 4.1 & 40 & 4.5 & 107 \\
\hline 600 & 4.3 & 29 & 4.5 & 86 & 5.1 & 136 \\
\hline
\end{tabular}

$\%$

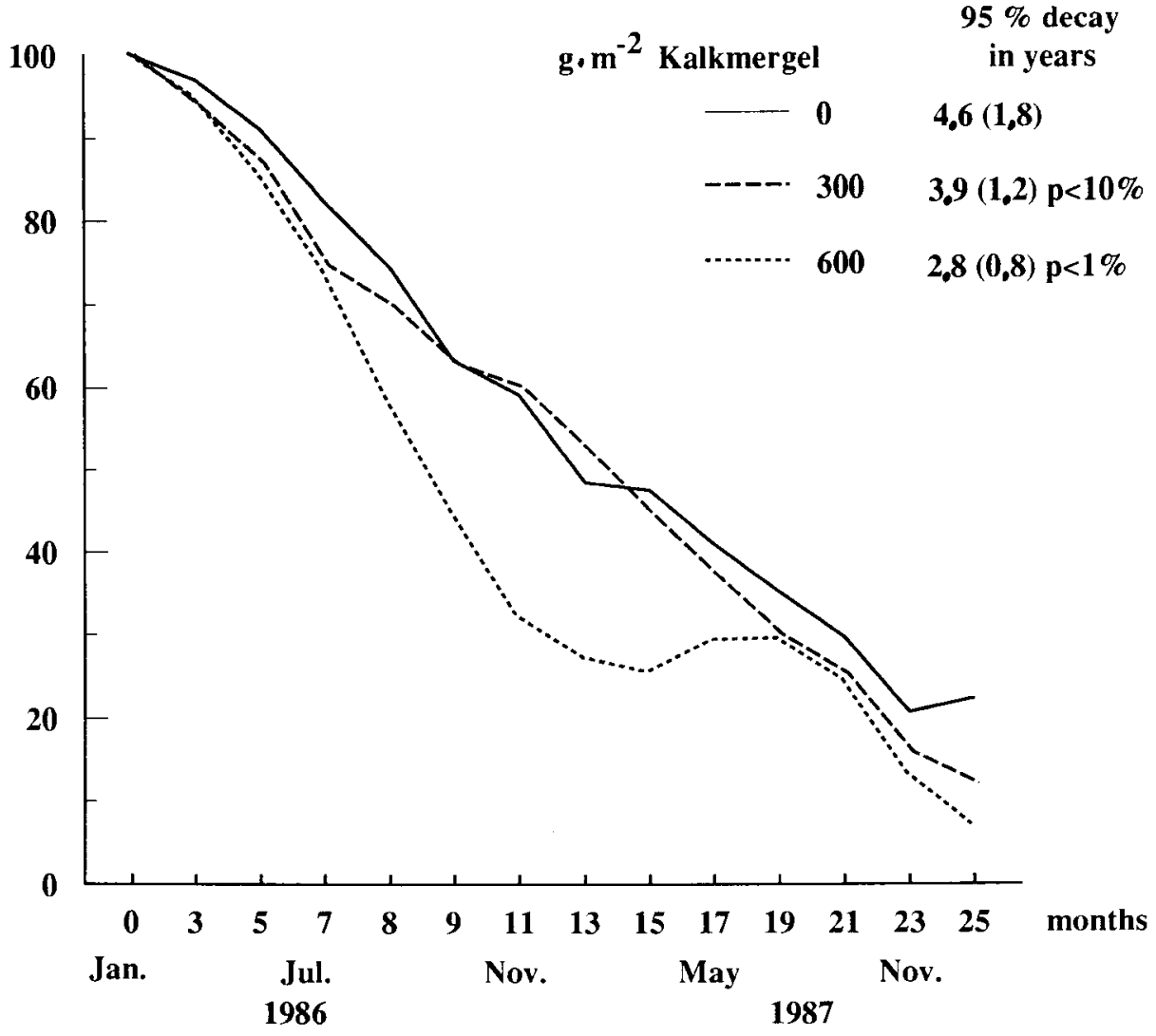

Fig 5. Loss of mass (in \%) of the leaf litter in the beech-oak forest in Siggen (Schleswig-Hostein) and time of $95 \%$ decomposition (standard deviation in brackets, error probability $(P)$ to $0 \mathrm{~g} / \mathrm{m}^{2}$ or $300 \mathrm{~g} /$ $\left.m^{2}\right)$. 
tree canopy. This is why only a small amount of herb vegetation is present. The low $\mathrm{C} / \mathrm{N}$ ratio of the necrotic herb vegetation would stimulate the soil animals (Dunger, 1983). The present bioturbation is not sufficient to counteract the observed translocation.

Liming at the soil surface with 3 tha of dolomite could moderate the soil acidification and stimulate the development of the soil herb vegetation. This would influence the soil animals (table III) and the litter decomposition in a positive way (fig 5). The higher abundance of decomposers induced by liming would cause an increase in litter decay. $300 \mathrm{~g} / \mathrm{m}^{2}$ of lime cause the decomposition time of litter to be reduced by a third and $600 \mathrm{~g} / \mathrm{m}^{2}$ cause it to be halved. The decomposition of the fallen litter is stimulated by liming and hinders the formation of a permanent organic layer.

\section{CONCLUSION}

The humus body of an Orthic Luvisol has changed during the past 25 years. The intensity of decomposition and humification has decreased and the humus form has changed from mull to moder. The translocation of fulvic acids has increased and first signs of podzolization have been recorded. The main reason for this may be the decline in the earthworm population because of the lower $\mathrm{pH}$ and the deficiency of calcium as a consequence of the acid and proton input by air pollution.

\section{ACKNOWLEDGMENTS}

The authors wish to thank $P$ Duchaufour for translating the French parts of this paper. This work has been supported financially by the Federal Ministry of Research and Technology (BMFT), Germany-Bonn-Bad Godesberg.

\section{REFERENCES}

Abrahamsen G, Hovland J, Hagvar S (1980) Effects of artificial acid rain and liming on soil organisms and the decomposition of organic matter. In: Effects of Acid Precipitation on Terrestrial Ecosystems (Hutchinson TC, Havas $\mathrm{M}$, eds) Plenum Press, NY, 341-362

AK Standortskartierung (1980) Forstliche Standortsaufnahme. Landwirtschaft, MünsterHiltrup, 4 Aufl

Baath E, Berg B, Lohm U, Lundgren B, Lundkvist, Rosswall $B$, Söderström B, Wiren A (1980) Effects of artificial acidification and liming on soil organisms and decomposition in a Scots pine forest. Pedobiologia 20, 85100

Beyer $L$ (1989) Nutzungseinfluss auf die Stoffdynamik schleswig-holsteinischer BödenHumusdynamik und mikrobielle Aktivität. Schriftenr Inst Pflanzenernaehr Bodenkd Univ Kiel 6

Blume HP (1965) Die Charakterisierung von Humuskörpern durch Streu- und HumusStoffgruppenanalysen unter Berücksichtigung ihrer morphologischen Eigenschaften. Z Pflanzenernaehr Dueng Bodenkd 111, 95113

Blume HP, Lamp J, Schimming CG, Wiese D, Zingk M (1985) Bodenbelastung aus der Luft? Publ Agric Fac Univ Kiel 67, 44-51

Blume HP, Lamp J, Schnug E, Wiese D (1986) Typical soils and landscapes in Holstein. Mitt Dtsch Bodenkundl Ges 51, 14-42

Brewer R, Sleeman JR (1960) Soil structure and fabric. J Soil Sci 11, 172-185

Diagne A (1982) Effects d'une fertilisation minerale sur l'humification, les cycles biologiques et la productivité d'une hêtraie acidiphile sur grès de l'est de la France. Thèse, Univ Nancy

Duchaufour $P$ (1987) Influence de la mise en culture sur les propriétés de deux sols forestiers du Holstein. CR Acad Agric Fr 73, 5-10

Dunger W (1983) Tiere im Boden. Ziemsen, Wittenberg

Hallbäcken L, Tamm CO (1986) Changes in soil acidity from 1927 to $1982-1984$ in a forest area of south-west Sweden. Scand J For Res 1, 219-232 
Hartmann P, Scheitler A, Fischer R (1989) Soil fauna comparisons in healthy and declining Norway spruce stands. In: Forest Decline and Air Pollution (Schulze ED, Lange OL, Oren R, eds) Springer, Berlin, 137-150

Kreutzer K (1989) Änderungen im Stickstoffhaushalt der Wälder und die dadurch verursachten Auswirkungen auf die Qualität des Sickerwassers. In: DVWK-Mitteilungen 17: Immissionsbelastung des Waldes und seiner Böden-Gefahr für die Gewässer? DVWK, 121-132

Lee KE (1985) Earthworms. Academic Press, Sydney

Olson JS (1963) Energy storages and balance of producers and decomposers in ecological systems. Ecology 44, 322-331

Schlichting E, Blume HP (1966) Bodenkundliches Praktikum. P Parey, Hamburg

Ulrich B, Meiwes J, König N, Khanna PK (1984) Untersuchungsverfahren und Kriterien zur Bewertung der Versauerung und ihrer Folgen in Waldböden. Forst Holz 39, 278-286
Ulrich B (1989a) Stand der Göttinger Waldschadensforschungeine Kurzfassung. Forst Holz $16,419-422$

Uirich B (1989b) Depositionsbedingte Veränderungen von Waldböden. Österr Forstz 3

Ulrich B, Meyer H, Jänich K, Büttner G (1989) Basenverluste in den Böden von Hainsimsen-Buchenwäldern in Südniedersachsen zwischen 1954-1986. Forst Holz 44, 251-253

von Zezschwitz E (1979) Profilmorphologische Merkmale der Anfangsstadien der Podsolierung (Podsoligkeit). Geol Jahr F 7, 87-107

von Zezschwitz E (1980) Analytische Kennwerte typischer Humusformen westfälischer Bergwälder. Z Pflanzenernaehr Bodenk 143, 692700

von Zezschwitz E (1985) Immissionsbedingte Änderungen analytischer Kennwerte nordwestdeutscher Mittelgebirgsböden. Geol Jahr $F 20,3-41$

von Zezschwitz $E$ (1989) Humusformen unter Wandel. Mitt Dtsch Bodenkundl Ges 59/II, 1249-1254 